this damage can be greatly reduced by adding $4 \mathrm{lb}$. of ferrous sulphate crystals to every gallon of limesulphur concentrate before dilution. Sprays against apple scab were made according to the usual schedule. The relative effects of calcium arsenate and lead arsenate separately mixed with lime sulphur as post-blossom sprays were also estimated. Calcium arsenate powder proved more toxic to the apple leaves than lead arsenate paste of much less arsenic oxide equivalent. The inclusion of ferrous sulphate in the mixtures, however, reduced the leaf-drop; but did not markedly prevent fruit-drop. Zine sulphate provided no suitable alternative to ferrous sulphate ; it was highly phytotoxic.

\section{Parallelism between Atomic and Planetary Properties}

A SHorT article with the above title in Nature of May 15, p. 780 , directed attention to the formulation by M. F. Prunier of a wave equation for astronomical planetary systems similar to Schrödinger's equation for atomic systems. It has just been brought to our notice that a somewhat similar hypothesis had been put forward earlier by Mr. B. Liebowitz, of New York (Phys. Rev., 66, 343; 1944). His equation is satisfied by a variable which he calls the "probability of presence". The subsequent development, very surprisingly, seems to show that for a purely classical problem concerning the planets, akin to Bode's law, using purely classical arguments, an equation can be obtained which has the same form and meauing as Schrödinger's essential non-classical equation. But, in sharp opposition to the conclusion of M. Prunier, Mr. Liebowitz says that there is no implication of a magnetic moment associated with the angular momentum. It will be recalled that the possibility of such a relation, particularly for the earth's mag. netism, has been much discussed since Prof. Blackett's article in Nature $(159,658 ; 1947)$ was published.

\section{The Coco-nut Research Scheme}

THE annual report for 1944 of the Coco-nut Research Scheme (Government Record Office, Colombo, Ceylon, 40 cents, 20 pp., Jan., 1948) shows that in addition to many routine analyses of copra and coco-nut products, a more detailed examination of the dry distillation of coco-nut shells has been made. The yield of pyrolig. neous acid was 38.2 per cent and of settled tar, 5.6 per cent. Total acid (as acetic) accounted for 11.6 per cent of the pyroligneous acid, which also contained about 3 per cent of wood spirit. An attempt to use coco-nut shells as a starting material for the preparation of furfurol gave rather poor yields. Manurial experiments with nitrogen, phosphorus and potash indicate that only the potash increased the yield of copra, beginning at the fourth year from commencement of applications. On poor soils, complete manuring with all three major nutrients gave a marked increase in the number of female flowers. Various other experiments on cultivation are also described in the report.

\section{The Royal Anthropological Institute}

THE report of the Council of the Royal Anthropological Institute for July, 1947-June, 1948 has appeared. It is pleasing to gather that real progress has been made in all directions. The Institute has always been handicapped through lack of means and in other ways. Though these disabilities have by no means all been overcome, improvement can be clearly noted. The membership is rising, and the library is now in better order. Much activity has been shown in many directions. The Institute fulfils an important function in a country like Great Britain which lies at the centre of a great Empire, and every effort should be made to help it to do what it alone can accomplish for the study and understanding of the many primitive peoples it is still our lot to sustain.

\section{Erdoel und Kohle}

The former German oil journal, Oel und Kohle, has now appeared under the title Erdoel und Kohle (von Hernhaussen, Hamburg; annual subscription, 60 marks). The first issue of 56 pages was brought out by Dr. Karl Zerbə in June. Its contents cover the future problems of petroleum geology and geophysies and the possibilities of applying secondary recovery methods. In the refining section there are articles on the progress of hydrocarbon synthesis and dewaxing. Scientific abstracts and short commercial notices are included. This journal is the official organ of several technical associations.

\section{Seventh Pacific Science Congress}

THE Seventh Pacific Science Congress will be held in Auckland and Christchurch, New Zealand, under the auspices of the Royal Society of New Zealand, and with the assistance of the Government of New Zealand, during February 2-22, 1949. As in previous Congresses, members will be classified as official members (delegates representing the constituent countries of the Pacific Science Association and specially invited guests), members (accredited by scientific bodies) and participants. The Congress will be organised in ten divisions, and within divisions there will be a varying number of sections. The programme is arranged in the form of symposia for the discussion of topics of wider interest for the Pacific peoples ; within divisions, subjects of specialist or technical interest will be presented at section meetings. Among the subjects for symposia are : structure of the Pacific basin ; Antarctic and Pacific meteorology; oceanography and fisheries of the Pacific; biogeographical provinces; soil resources; ethnographic studies in Micronesia ; medical and nutritional problems of the Pacific area. The president of the Congress is Mr. R. A. Falla, president of the Royal Society of New Zealand and director of the Dominion Museum, Wellington; the secretary general is Mr. Gilbert Archey, director of the Auckland Institute and Museum, Auckland, S.E.1, to whom all communications should be addressed.

\section{Announcements}

THE Queen has been graciously pleased to aceord her patronage to the Royal Society of Edinburgh, of which H.M. the King is patron.

AT the National Gallery, London, Mr. Martin Davies, who is chiefly in charge of the library, and Mr. Ian Rawlins, scientific adviser, have been appointed deputy keepers.

Mr. J. V. ConNoLLY, who has served since 1937 at the Air Ministry, Ministry of Aircraft Production and Ministry of Supply, recently as assistant director of aircraft production, has been appointed professor of aircraft economics and production at the College of Aeronautics. 